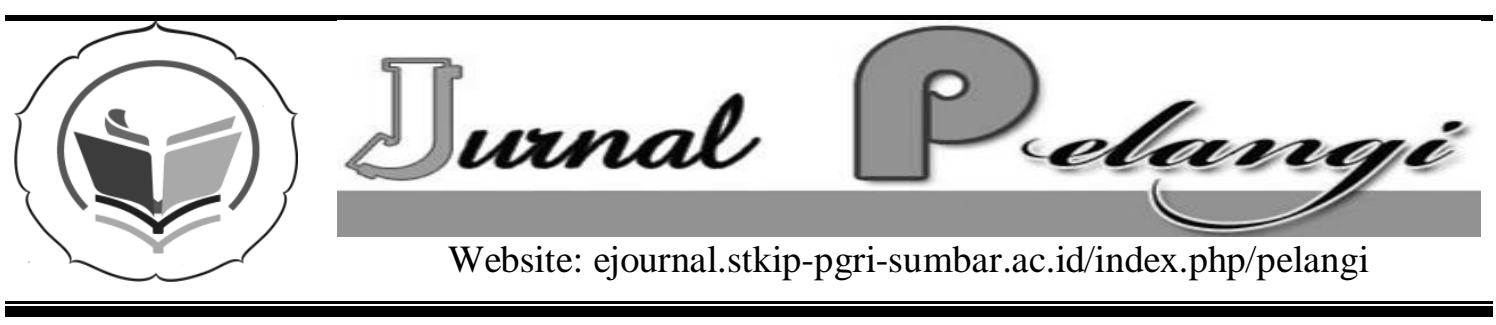

\title{
ANALISIS KETERAMPILAN MENGAJAR GURU TERHADAP PEMBELAJARAN MATEMATIKA DI KELAS X SMK
}

\author{
Fajar Sukma Harsa
}

Pendidikan Matematika Pascasarjana UNIMED

fajarsukmaharsa@rocketmail.com

\section{INFO ARTIKEL}

Diterima:

9 April 2017

Direview:

20 April 2017

Disetujui:

3 September 2017

Kata Kunci:

management of learning mathematics, student's responses
Keywords:

\begin{abstract}
Abstrak
Suatu kondisi belajar yang optimal akan dapat tercapai jika guru mampu mengatur anak didik dan sarana pengajaran serta mengendalikannya dalam suasana yang menyenangkan untuk mencapai tujuan pengajaran. Efektifitas pengelolaan pembelajaran oleh guru dapat dilihat dari berbagai segi, misalnya dalam hal menyusun rencana pembelajaran, melaksanakan pembelajaran, serta menilai prestasi belajar. Guru matematika memiliki peran utama dalam pengelolaan pembelajaran matematika. Idealnya, seorang guru harus memperhatikan aspek-aspek pengelolaan pembelajaran matematika yang tercakup dalam perencanaaan, pengorganisasian, pelaksanaan dan penilaian hasil pembelajaran. Penelitian ini menggunakan pendekatan kualitatatif. Lokasi penelitian adalah Sekolah Menengah Kejuruan (SMK) Ar-Rahman Medan Subjek penelitian adalah Siswa/i Kelas X SMK Ar-Rahman sebanyak 29 orang dan guru mata pelajaran matematika. Data Penelitian meliputi Informan yaitu guru dan siswa. Teknik pengumpulan data melalui Lembar observasi guru dalam kegiatan pembelajaran dan Angket Responsif siswa kegiatan pembelajaran. Secara keseluruhan, pengelolaan pembelajaran yang dilakukan oleh guru sudah baik, sebab dari 16 aspek yang dinilai hanya dua aspek saja yang tidak terpenuhi. Respon siswa terhadap pembelajaran dan perangkat menunjukkan respon positif. Pertanyaan (1), (3), dan (5), respon positif melebihi $70 \%$ yang menunjukkan minat dan semangat belajar siswa yang cukup tinggi. Hal tersebut menjadi penguatan bahwa pengelolaan pembelajaran yang baik oleh guru akan berdampak baik bagi siswa.
\end{abstract}

\section{Abstract}

An optimal learning conditions will be achieved if the teachers 
Elementary of Statistics, Module, Software R, CTL organize students and teaching facilities and also control it in a pleasant atmosphere to achieve the goal of teaching. Effective management of learning by teachers can be viewed from various aspects, for example in terms of preparing lesson plans, teaching implement, and assess learning achievement. The math teacher had a major role in the management of learning mathematics. Ideally, a teacher must pay attention to the management aspects of mathematics covered in of planning, organizing, implementation and assessment of learning outcomes. This research use qualitatively. This research is located Vocational High School (SMK) Ar-Rahman Medan tenth grade class whic consists 29 students. Data research included informants those are teachers and students. The technique of collecting data through observation sheets teachers in learning activities and Questionnaire Responsive student learning activities. Overall, the management of learning undertaken by teachers has been good, because of the 16 aspects assessed only two aspects are not met. Learning and the students' response to the device indicates a positive response. Question (1), (3) and (5), the positive response exceeds $70 \%$, showing the interest and enthusiasm of student learning is quite high. It became reinforcement that good management of learning by teachers will be good for students

\section{PENDAHULUAN}

Pendidikan adalah salah satu indikator yang menentukan baik atau buruknya suatu bangsa. Sehingga melalui dasar pemikiran apapun, upaya peningkatan mutu dan kualitas pendidikan haruslah menjadi cacatan penting dan objek utama kajian dalma rangka memperbaiki bangsa dan negara. Indra (2001:23) menyampaikan bahwa paradigma dan visi pendidikan yang lebih relevan dengan kondisi zaman diturunkan ke dalam metode pembelajaran. Karena itu, pembicaraan tentang metode pengajaran dengan sendirinya menuntut peningkatan dan penyesuaian kualitas SDM para pengelola, guru juga pada akhirnya pada siswa. Pembelajaran tidak bisa dipisahkan dengan proses belajar mengajar. Belajar berarti upaya untuk memahami dan mendapatkan ilmu. Sedangkan mengajar adalah usaha untuk menyampaikan dan memahamkan ilmu. Lebih lanjut, Fetty (2013:165) menyampaikan kegiatan belajar mengajar adalah suatu bentuk penyelenggaraan pendidikan yang memadukan secara sistematis dan berkesinambungan kegiatan pendidikan di dalam lingkungan sekolah dengan kegiatan pendidikan yang dilakukan di luar lingkungan sekolah dalam wujud penyediaan beragam pengalaman belajar untuk semua peserta didik. Oleh karena itu pengelolaan pembelajaran yang baik oleh seorang guru dapat meningkatakan pemahaman terhadap pelajaran.

Suatu kondisi belajar yang optimal akan dapat tercapai jika guru mampu mengatur anak didik dan sarana pengajaran serta mengendalikannya dalam suasana yang menyenangkan untuk mencapai tujuan pengajaran, juga hubungan interpersonal yang baik antara guru dan anak didik, dan anak didik dengan anak didik merupakan syarat keberhasilan pengelolaan kelas.

Efektifitas pengelolaan pembelajaran oleh guru dapat dilihat dari berbagai 
segi, misalnya dalam hal menyusun rencana pembelajaran, melaksanakan pembelajaran, serta menilai prestasi belajar. Hal ini sejalan dengan pendapat Oemar Hamalik (2005:84) yang menyatakan bahwa, "pengelolaan kegiatan pembelajaran antara lain meliputi penyusunan rencana pembelajaran, pelaksanaan pembelajaran, dan penilaian hasil belajar". Pengelolaan tersebut pada akhirnya akan bermuara pada efektif tidaknya proses pembelajaran dan tinggi rendahnya motivasi siswa di dalam mengikutinya. Pembelajaran yang efektif memiliki dampak pada motivasi belajar siswa. Pembelajaran yang efektif akan membuat siswa merasa tertarik untuk mengikutinya. Adanya motivasi inilah yang mendorong siswa untuk melakukan kegiatan belajar.

Berdasarkan Undang-Undang nomor 14 tahun 2005 tentang Guru dan Dosen, pada pasal 10 ayat menyatakan bahwa kompetensi guru meliputi kompetensi pedagogik, kompetensi kepribadian, kompetensi sosial, dan kompetensi profesional. Adapun uraian kompetensi-kompetensi tersebut sebagai berikut:

(1) Kompetensi Pedagogik yaitu kemampuan pemahaman terhadap peserta didik, perancangan dan pelaksanaan pembelajaran, evaluasi hasil belajar, dan pengembangan peserta didik untuk mengaktualisasikan berbagai potensi yang dimilikinya.

(2) Kompetensi Kepribadian yaitu kemampuan personal yang mencerminkan kepribadian yang mantap, stabil, dewasa, arif dan berwibawa, serta menjadi teladan bagi peserta didik.

(3) Kompetensi Profesional yaitu kemampuan penguasaan materi pembelajaran secara luas dan mendalam, yang mencakup penguasaan materi kurikulum mata pelajaran di sekolah dan substansi keilmuan yang menaungi materinya, serta penguasaan terhadap struktur dan metodologi.

(4) Kompetensi sosial yaitu kemampuan guru untuk berkomunikasi dan bergaul secara efektif dengan peserta didik, tenaga kependidikan, orangtua/wali peserta didik, dan masyarakat sekitar.

Dilihat dari proses pembelajaran, kompetensi pedagogik merupakan kompetensi utama dalam pengelolaan pembelajaran (Putri Balqis dkk, 2014), sebab kemampuan pedagogik gurulah yang menjadi salah satu indikator penting baik atau tidak pembelajaran. Dalam kompetensi pedagogik, perancangan pembelajaran meliputi analisis materi pembelajaran yang memuat tentang standar kompetensi, kompetensi dasar, indikator dan materi pokok (Harun, 2010), dan selanjutnya diwujudkan melalui rancangan program pembelajaran (RPP). Kemudian, proses pembelajaran yang meliputi kegiatan awal atau apersepsi, kegiatan inti, dan kegiatan penutup adalah sarana bagi peserta didik untuk mengembangkan dan mengaktualisasikan potensi diri mereka. Dan terakhir, evaluasi belajar digunakan untuk mengidentifikasi perkembangan peserta didik melalui intsrumen tes yang sesuai dengan kompetensi dasar.

Pembelajaran matematika merupakan suatu upaya/kegiatan (merancang dan menyediakan sumber-sumber belajar, membantu/membimbing, memotivasi, mengarahkan) dalam membelajarkan siswa untuk mencapai tujuan pembelajaran matematika (Hudojo, 2005). Pentingnya hal tersebut karena didasari bahwa matematika mempunyai peranan krusial dalam perkembangan ilmu pengetahuan maupun dalam kehidupan sehari-hari. 
Penguasaan teknologi sebagai syarat untuk dapat mengikuti perkembangan zaman dalam era global tidak lepas dari peran matematika, sebab untuk mampu menguasai teknologi dengan baik dibutuhkan kemampuan matematika yang baik pula. Dienes (dalam Karso dkk, 2006) mengemukakan bahwa belajar matematika melibatkan suatu struktur hirarki dari konsep-konsep tingkat tinggiyang dibentuk atas dasar apa yang telah dibentuk sebelumnya. Artinya, konsep-konsep matematika yang diajarkan oleh guru haruslah berkaitan dengan konsep sebelumnya dan menjadi dasar untuk memhami konsep selanjutnya. Tentu hal tersebut sangatlah membutuhkan peran penting seorang guru dalm proses pengajaran dan pembelajaran matematika Namun kenyataan di lapangan, pengelolaan pembelajaran matematika belum berjalan sesuai harapan. Berdasarkan penelitian Sutama (2013) pembelajaran matematika di Sekolah cenderung text book oriented dan kurang terkait dengan kehidupan sehari-hari siswa, serta cenderung abstrak, sehingga konsep-konsep akademik sulit dipahami, sehingga berakibat, hasil belajar matematika belum sesuai harapan.Lebih lanjut, Fajar $(2012,2)$ mengemukakan bahwa proses pembelajaran matematika di kelas sangat ditentukan oleh pandangan seorang guru dan keyakinannya terhadap matematika, sebab ketidaksempurnaan memahami matematika dari seorang guru sedikit banyak akan menyebabkan ketidaksempurnaan pada proses pembelajaran di kelas.

Guru matematika memiliki peran utama dalam pengelolaan pembelajaran matematika. Idealnya, seorang guru harus memperhatikan aspek-aspek pengelolaan pembelajaran matematika yang tercakup dalam perencanaaan,

Tabel 1. Teknik Pengumpulan Data pengorganisasian, pelaksanaan dan penilaian hasil pembelajaran. Sutama (2011: 9-10) mengatakan bahwa pengelolaan pembelajaran matematika mengutamakan peran aktif siswa, guru berperan sebagai perancang, fasilitator, dan pembimbing proses pembelajaran. Oleh karena itu, dari uraian seluruh pendapat diatas, dapat disimpulkan begitu pentingnya peranan guru dalam pembelajaran matematika karena berkaitan erat dengan keberhasilan siswa dalam memahami dan mengaplikasikan matematika. Tujuan penelitian ini adalah (1) mendeskripsikan kualitas pengelolaan pembelajaran matematika dan (2) mendeskripsikan kondisi dan respons siswa dalam pembelajaran matematika.

\section{METODE PENELITIAN}

Penelitian ini menggunakan pendekatan kualitatatif. Penelitian kualitatif adalah penelitian yang menghasilkan prosedur analisis dan tidak menggunakan prosedur analisis statistikinferensial.Menurut Sutama (2010: 32) penelitian kualitatif lebih diarahkan untuk memahami fenomenafenomena sosial dari perspektif peneliti.

Lokasi penelitian adalah Sekolah Menengah Kejuruan (SMK) Ar-Rahman Medan Subjek penelitian adalah Siswa/i Kelas X SMK Ar-Rahman sebanyak 29 orang dan guru mata pelajaran matematika, sedangkan objek adalah pengelolaan pembelajaran dalam kelas. Data Penelitian meliputiInforman yaitu guru dan siswa, sedangkan teknik analisis data menggunakan analisis kualitatif.

Data utama yang akan dikumpulkan serta teknik pengumpulan data selama pelaksanaan penelitian dapat dilihat pada tabel 1 . 


\begin{tabular}{ccc}
\hline No & Jenis Data & \multicolumn{1}{c}{ Teknik pengumpulan } \\
\hline 1 & $\begin{array}{l}\text { Kemampuan guru } \\
\text { mengelola kelas }\end{array}$ & Lembar observasi guru dalam kegiatan pembelajaran \\
\hline 2 & Responsif siswa & Angket Responsif siswa kegiatan pembelajaran \\
\hline
\end{tabular}

\section{HASIL DAN PEMBAHASAN}

Observasi yang dilakukan untuk mendeskripsikan pengelolaan pembelajaran oleh guru adalah melalui lembar observasi yang terdiri dari beberapa aspek penilaian berdasarkan kegiatan awal, inti, dan penutup pembelajaran.

Kegiatan Awal terdiri dari aspek sebagai berikut:

(1) membuka pelajaran dengan mengomunikasikan tujuan pembelajaran,

(2) membahas hal - hal yang diketahui dan dipahami peserta didik,

(3) memotivasi dan merangsang peserta didik dengan bahan ajar yang menarik dan berguna bagi peserta didik, dan

(4) mendorong peserta didik agar tertarik untuk mengetahui hal - hal baru.

Hasil observasi menunjukkan keempat aspek pada kegiatan awal tersebut sudah dilakukan oleh guru. Saat memulai pelajaran guru terlebih dahulu menyampaikan salam dan topik pelajaran yang akan dipelajari untuk pertemuan hari ini. Selanjutnya, guru melakukan kilas balik pelajaran sebelumnya dengan bertanya kepada siswa, jika ada yang masih belum paham, maka guru mengulang kembali dengan singkat pelajaran tersebut. Setelah siswa terlihat siap memulai pelajaran baru, guru memberikan pertanyaan sebagai upaya meningkatkan rasa ingin tahu siswa sehingga bersemangat saat proses pembelajaran berlangsung. Peneliti mencatat beberapa pertanyaan yang disampaikan guru kepada siswa yaitu: Menurut kalian, untuk apakah digunakan matriks? Apa manfaat belajar matriks? Bisakah kalian tunjukkan contoh disekeliling kita kumpulan bilangan-bilangan yang membentuk baris dan kolom atau disebut dengan matriks? Pertanyaan-pertanyaan tersebut menunjukkan peran guru dalam meningkatkan pemahaman siswa dan menciptakan ketertarikan kepada pelajaran matematika.

Kegiatan Inti terdiri dari aspek sebagai berikut:

(1) mengenalkan materi atau keterampilan baru,

(2) mengkaitkan materi itu dengan pengetahuan yang sudah ada pada peserta didik

(3) mengembangkan pemikiran pserta didik untuk melakukan kegiatan belajar lebih bermakna, apakah dengan cara bekerja sendiri, menemukan sendiri, dan mengkonstruksi sendiri pengetahuan dan keterampilan barunya,

(4) melibatkan peserta didik secara aktif dalam menafsirkan dan memahami materi,

(5) mengembangkan sifat ingin tahu siswa melalui memunculkan pertanyaan - pertanyaan,

(6) memberikan respon atas pertanyaan siswa,

(7) melibatkan siswa secara katif dalaam memecahkan masalah dan menciptakan masyarakat belajar, seperti melalui kegiatan kelompok berdiskusi, tanya jawab, dan lain sebagainya

(8) menghadirkan model sebagai contoh pembelajaran, bisa melalui ilustrasi, 
model bahkan media yanh sebenarnya, dan

(9) mendorong peserta didik untuk menerapkan konsep/pengertian yang dipelajarinya dalam kehidupan sehari - hari,

Hasil observasi menunjukkan bahwa semua aspek (1), (2), (4), (5), (6), (7), dan (8) pada kegiatan inti tersebut sudah dilakukan oleh guru. Terlihat guru mampu memainkan peran sebagai pendidik dan memahami kondisi masing-masing siswa. Guru berupaya untuk sering berinteraksi dengan siswa. Materi "MATRIKS" yang disampaikan oleh guru sangat runtun dan sesuai dengan buku ajar, sehingga siswa tidak bingung untuk memahaminya. Jika ada yang ribut, guru tidak langsung mengintimidasi dan memberikan hukuman langusng, namun dengan peringatan dan nasihat. Walaupun pada keseluruhannya pada kegiatan inti sudah baik, namun pada aspek (3) dan (9) masih belum terpenuhi. Guru belum mampu mengembangkan pembelajaran bermakna dan mengonstruksi konsep dengan cara siswa sendiri, sehingga pembelajaran terkesan hanya "transfer" ilmu, guru hanya mengajar dan tidak membelajarkan. Begitu juga dengan kurangnya motivasi guru untuk menyampaikan manfaat materi yang disampaikan dalam kehidupan seharihari. Hal ini kurang memainkan peran matematika sebagai pelajaran yang punya kebermanfaatan bagi kehidupan dan sebagai solusi atas permasalahanpermasalahan yang ada.

Terakhir, kegiatan penutup terdiri dari aspek sebagai berikut:

(1) membiasakan peserta didik untuk melakukan refleksi dari setiap kegiatan pembelajaran yang telah dilakukan , dan

(2) mengembangkan cara - cara untuk menilai hasil pembelajaran peserta didik salah satunya dnegan penilaian secara objektif, yaitu menilai kemampuan yang sebenarnya pada siswa,

(3) menutup pelajaran

Pada kegiatan penutup atau akhir, guru tetap memberikan refleksi pembelajaran dan menyimpulkan inti pelajaran yang telah disampaikan, sehingga siswa masih diberi kesempatan untuk mereview atau mengecek materimateri yang ketinggalan.

Secara keseluruhan, pengelolaan pembelajaran yang dilakukan oleh guru sudah baik, sebab dari 16 aspek yang dinilai hanya dua aspek saja yang tidak terpenuhi. Menurut Deviliati (2015) keterampilan guru mengajar dan sebuah kelas yang dikatakan tertib dapat disimpulkan dari indikator pengelolaan kelas yaitu: (1) menguasai bahan pelajaran yang disampaikan kepada siswa, (2) menguasai kelas sehingga dapat mengendalikan kegiatan siswa, (3) guru mengupayakan agar siswa sesegera mungkin dapat menyelesaikan tugas yang diberikan, dan (4) guru tidak mendisiplinkan siswa dengan ancamanancaman, dan konsekuensi seperti penghilangan hak siswa dan lain-lain. Oleh karena itu dapat disimpulkan bahwa pengelolaan pembelajaran matematika yang dilakukan oleh guru pada kelas X SMK Ar-Rahman Medan sudah baik dan tertib.

Angket respon siswa dibuat untuk melihat sejauh mana ketertarikan siswa, perasaan senang serta kemudahan dalam memahami materi pelajaran matematika yang disampaikan oleh guru.

Hasil Angket Respon siswa dari 6 pertanyaan yang dibuat oleh peneliti adalah:

(1) Untuk pertanyaan "Apakah kamu memahami keseluruhan materi matematika yang disampaikan oleh guru ?", 27 siswa (93\%) menjawab 
memahami sebagian, 2 siwa $(7 \%)$ memahim keseluruhan, dan tidak siswa yang tidak paham apa yang disampaikan oleh guru.

(2) Untuk pertanyaan "Apakah kamu tertarik dengan materi matematika yang disampaikan oleh guru ?, 8 siswa $(28 \%)$ mengatakan sangat tertarik, 13 siswa (44\%) tertarik, dan 8 siswa (28\%) kurang tertarik

(3) Untuk pertanyaan "Apakah gurumu menyampaikan materi matematika dengan jelas?, 21 siswa (72\%) menjawab sangat jelas, 6 siswa (21\%) menjawab jelas, dan 2 siswa (7\%) menjawab kurang jelas.

(4) Untuk pertanyaan "Jika disuruh memilih, media tambahan apa yang kamu sukai saat pelajaran matematika selain spidol dan papan tulis ?, 26 siswa (90\%) menjawab cukup hanya pakai spidol dan papan tulis, dan 3 siswa (10\%) menjawab pakai infokus/proyektor

(5) Untuk pertanyaan "Apakah kamu selalu bertanya ketika gurumu menjelaskan pelajaran matematika ?, 24 siswa (83\%) menjawab kadang-kadang, 4 siswa $(14 \%)$ menjawab tidak pernah, dan 1 siswa (1\%) menjawab sering

Respon siswa terhadap pembelajaran dan perangkat menunjukkan respon positif yang meliputi pemahaman, ketertarikan, kejelasan materi, dan tingkat antusias siswa. Pertanyaan (1), (3), dan (5), respon positif melebihi $70 \%$ yang menunjukkan minat dan semangat belajar siswa yang cukup tinggi. Hal tersebut menjadi penguatan bahwa pengelolaan pembelajaran yang baik oleh guru akan berdampak baik bagi siswa. Namun pada pertanyaan (2) ternyata $28 \%$ siswa tidak tertarik dengan pelajaran matematika. Ketidaktertarikan siswa dengan matematika bisa jadi disebabkan guru kurang menyampaikan kebermanaknaan pelajaran matematika dalam kehidupan sehari-hari. Begitupun pada pertanyaan (5) $83 \%$ siswa lebih menyukai media konvesional yang bermodalkan spidol dan papan tulis. Sebenarnya hal tersebut sah-sah saja jika siswa lebih paham ketika guru hanya bermodalkan media wajib (spidol dan papan tulis) dalam mengajar, namun di zaman teknologi berkembang saat ini, adalah sebuah kewajiban seorang guru menggunakan bantuan teknologi untuk menambah minat dan perhatian siswa dalam pelajaran matematika. Abstraknya matematika akan terbantu dengan visualisasi dari media seperti infokus atau alat peraga. Oleh karena itu, guru haruslah meningkatkn keterampilan dalam menggunakan media ajar inovatif dan kreatif.

Pada dasarnya kegiatan guru, saat pelajaran pengajaran langsung menyangkut kegiatan menciatakan dan memelihara kondisi belajar yang memungkinkan pengelolaan pengajaran secara optimal. Pembelajaran matematika yang bermutu akan terjadi jika proses belajar yang dialami siswa dan proses mengajar yang dilakukan oleh guru efektif. Dimana untuk belajar matematika memerlukan kegiatan mental yang tinggi, karena matematika merupakan salah satu ilmu yang bersifat abstrak. Dikatakan profesional jika mampu mnguasai materi, mampu berkomunikasi dengan baik, mampu memilih metode mengajar yang baik. Dalam hal ini lebih lengkap di uraikan oleh Sudjana (2009:2) beberapa indikator dalam menilai kemampuan keterampilan guru mengajar yaitu; 1 . Menguasai bahan pelajaran yang disampaikan kepada siswa 2. Terampil berkomunikasi dengan siswa 3 . Menguasai kelas sehingga dapat mengendalikan kegiatan siswa 4. Terampil menggunakan berbagai alat dan sumber belajar 5. Terampil 
mengajukan pertanyaan baik lisan maupun tulisan.

Penelitian Sang Ayu (2011) mengatakan bahwa pengalaman guru berkontribusi positif dan signifikan terhadap kualitas pengelolaan pembelajaran matematika. Banyak faktor yang menyebabkan akhirnya seorang guru tidak mampu mengelola pembelajaran matematika seperti pengalaman guru, kondusivitas kelas, kemampuan siswa yang beragam, keterbartasan media ajar, serta fasilitas sekolah yang kurang memadai. Oleh karenanya, menjadi sebuah kewajiban bagi seorang guru dan sekolah untuk memperhatikan intensitas kualitas pengajaran agar tercapainya standar kualitas siswa yang tinggi.

\section{PENUTUP}

Suatu kondisi belajar yang optimal akan dapat tercapai jika guru mampu mengatur anak didik dan sarana pengajaran serta mengendalikannya dalam suasana yang menyenangkan untuk mencapai tujuan pengajaran, juga hubungan interpersonal yang baik antara guru dan anak didik, dan anak didik dengan anak didik merupakan syarat keberhasilan pengelolaan kelas.

Guru matematika memiliki peran utama dalam pengelolaan pembelajaran matematika. Idealnya, seorang guru harus memperhatika aspek-aspek pengelolaan pembelajaran matematika yang tercakup dalam perencanaaan, pengorganisasian, pelaksanaan dan penilaian hasil pembelajaran. Sutama (2011: 9-10) mengatakan bahwa pengelolaan pembelajaran matematika mengutamakan peran aktif siswa, guru berperan sebagai perancang, fasilitator, dan pembimbing proses pembelajaran.
Secara keseluruhan, pengelolaan pembelajaran yang dilakukan oleh guru sudah baik, sebab dari 16 aspek yang dinilai hanya dua aspek saja yang tidak terpenuhi. Respon siswa terhadap pembelajaran dan perangkat menunjukkan respon positif yang meliputi pemahaman, ketertarikan, kejelasan materi, dan tingkat antusias siswa. Pembelajaran matematika yang bermutu akan terjadi jika proses belajar yang dialami siswa dan proses mengajar yang dilakukan oleh guru efektif. Dimana untuk belajar matematika memerlukan kegiatan mental yang tinggi, karena matematika merupakan salah satu ilmu yang bersifat abstrak. Dikatakan profesional jika mampu mnguasai materi, mampu berkomunikasi dengan baik, mampu memilih metode mengajar yang baik.

\section{UCAPAN TERIMA KASIH}

Ucapan terima kasih yang sebesarbesarnya saya ucapkan kepada Prof.Dr. Hasratuddin Siregar, M.Pd yang bersedia memebrikan bimbingan dan arahan dalam penulisan jurnal peneilitian ini sehingga selesai dan dapat dinikmati para pembaca.

\section{DAFTAR PUSTAKA}

Balqis, Putri dkk. (2014). Kompetensi Pedagogik Guru dalam Meningkatkan Motivasi Belajar Siswa Pada SMPN 3 Ingin Jaya Kabupaten Aceh Besar. Jurnal Administrasi Pendidikan Pascasarjana Universitas Syiah Kuala, Vol 2, No.1. pp 25-38

Harun, C. Z. (2010). Manajemen Sumber Daya Pendidikan. Yogyakarta : Pena PersadaHamalik, Omar. (2005). Proses Belajar Mengajar, Jakarta: Bumi Aksara

Hudojo, Herman. 2005. Pengembangan kurikulum dan Pembelajaran 
Matematika. Malang : UM Press IKIP Malang.

Karso, dkk. (2006). Pendidikan Matematika. Jakarta : Universitas Terbuka

Lestari, Sang Ayu. (2011). Kualitas Pengelolaan Pembelajaran Matematika Ditinjau Dari Pengalaman Mengajar, Beban Kerja Dan Kesejahteraan guru SMP Negeri di Kabupaten Bangli. Jurnal Administrasi Pendidikan UNDIKHSA, Vol 2, No.2 .

Novianti, Fety. (2013). Hubungan Efektifitas Pengelolaan Kegiatan Pembelajaran Oleh Guru Pendidikan Kewarganegaraan Dengan Motivasi Belajar Siswa Kelas X Smk Negeri I Pontianak. Jurnal Edukasi, Vol. 11, No. 2, Desember 2013
Shadiq, Fajar. (2012). Pembelajaran Matematika : Cara Meningkatkan Kemampuan Berpikir Siswa. Yogyakarta : Graha Ilmu.

Sidi, Indra Djati. (2001). Menuju Masyarakat Belajar. Jakarta : Paramadina

Sutama. (2013). Pengelolaan Pembelajaran Matematika Sekolah Standar Nasional. Delta Jurnal Pendidikan Matematika FKIP Universitas Pekalongan, Vol. 1, No.1, Januari 2013

Sutama. (2010). Metode Penelitian Pendidikan. Surakarta: Fairuz Media

$\begin{array}{cr}\text { Sutama. (2011). } & \text { Pengelolaan } \\ \text { Pembelajaran } & \text { Matematika, } \\ \text { Berbasis Aptitude } & \text { Treatment } \\ \text { Interaction. } & \text { Surakarta: } \\ \text { Muhammadiyah University Press. }\end{array}$

